Magdalena Szpunar

Uniwersytet Jagielloński

e-mail: magdalena_sz@wp.pl

Otrzymano/Received: 26.04 .2020

Zaakceptowano/Accepted: 8.11.2020

Opublikowano/Published: 11.12.2020

\title{
Pycha w nauce
}

\section{Abstract}

\section{Pride in Science}

This article is dedicated to the category of pride, which I treat much more widely than a trait of an individual. In my article, I try to determine how specific representations of pride in the scientific community are manifested, what they result from, but I also explain what types of pride can be distinguished in science and what consequences it has for the entire scholarship.

Keywords: technocratic pride, scholars pride, innovative pride, scientist pride, scholar's moral conditions, education for ignorance

Słowa kluczowe: pycha technokratyczna, pycha scholarska, pycha nowatorska, pycha scjentystyczna, warunki moralne uczonego, edukowanie do niewiedzy

Praca naukowa przynależy do szczególnie nobilitujących aktywności człowieka. Celem artykułu jest eksploracja i diagnoza tego, co w Akademii zepchnięte do strefy jungowskiego Cienia, wyparte, niedostrzegane i eliminowane z oficjalnego dyskursu. To, co niewypowiedziane, o czym mówi się niechętnie, stanowi doskonały probierz tego, co problematyczne, z czym nie do końca jako akademicy sobie radzimy. Przyjęcie postawy „nie dostrzegam - nie istnieje” staje się zwalniającą nas od troski, wygodną ramą. Wytrącanie ze strefy komfortu, zadawanie trudnych, czasami bolesnych pytań traktuję jako naczelne zadanie nauki, co niniejszy tekst - przynajmniej w niewielkim stopniu - ma aspiracje uczynić. Przedstawiany artykuł poświęcony 
został kategorii pychy, którą traktuję znacznie szerzej niż właściwość osobniczą jednostki. W pracy próbuję określić, jak przejawiają się konkretne reprezentacje pychy w środowisku naukowym, z czego one wynikają, wyjaśniam również, jakie typy pychy można wyróżnić w nauce oraz jakie konsekwencje rodzi ona dla całego środowiska uczonych.

\section{Warunki moralne uczonego}

Wydaje się, iż praca naukowa należy do szczególnie nobilitujących form aktywności człowieka. Zasadniczym motorem działalności uczonych jest zwykle pasja i ciekawość poznawcza. Od wielu lat w rankingach zawodów profesor uniwersytetu lokuje się na szczycie najbardziej prestiżowych profesji. Współczesna nauka bardzo wyraźnie ewoluowała od koncepcji autonomicznej republiki Michaela Polanyiego (1962) ku akademii wyraźnie podlegającej polityce i uwarunkowaniom społeczno-kulturowym (Krimsky 2006, s. 22-29; Kwiek 2015), włącznie z hegemonią opłacalnościowej logiki korporacyjnej ${ }^{1}$. Próbując dookreślić role i funkcje nauki, możemy powiedzieć, iż „podejmuje [ona - dop. M.S.] walkę o prawdę, która jest jej istotnym celem, walcząc ze słabościami ludzkiej natury, aby eliminować z niej zło i zapewnić jej wiarygodność i prestiž" (Gibiński 2001, s. 8). Tak przynajmniej zakłada idealny model jej funkcjonowania. O tym, że nierzadko odbiega on od modelu pożądanego, nie trzeba specjalnie przekonywać. Dlaczego tak się dzieje i jakie są konsekwencje ubożenia uniwersytetu i jego pracowników, postaram się wykazać w niniejszym tekście.

Rozpocząć wypada od dość banalnego w gruncie rzeczy przypomnienia, iż każdego człowieka, niezależnie od tego, czym się zajmuje, powinna obowiązywać etyka „porządnego człowieka” (Kotarbiński 1987, s. 467). W przypadku pracowników nauki wydaje się ona szczególnie ważna i pożądana. Z wykonywaniem zawodu akademika wiąże się wiele powinności, dlatego też kluczowe wydaje się określenie tego, co Józef Pieter określa mianem „warunków moralnych” uczonego. Pieter zalicza do nich: ścisłość i dokładność naukową, skromność, pracowitość, cierpliwość, odporność na brak uznania i na niepowodzenia (por. Szpunar 2017a) oraz uczciwość (Pieter 1967, s. 395). Szczególnie ważne w kontekście naszych wyrażań, które ogniskują się wokół kategorii pokory, wydają się dwie cechy - skromność oraz odporność na brak uznania.

1 Przez kategorię „opłacalnościowej” logiki korporacyjnej rozumiem zamieranie autentycznej pasji czy ciekawości poznawczej na rzecz tego, co się „opłaca”, co przynieść może punkty i wysoką pozycję w rankingach uniwersyteckich (por. Szpunar 2019a, s. 95-104). 


\section{Intelektualna pokora wobec przedmiotu poznania a wartość i znaczenie kategorii „nie wiem”}

Uczonych powinien charakteryzować określony wzór osobowy, który stanowi nic innego jak powinność nakładaną na naukowców przez społeczeństwo (Znaniecki 1984). Ów wzór osobowy ma charakter procesualny, stanowiąc długi cykl trwania, aż do momentu osiągnięcia (bądź też nie) wymaganych kompetencji. W chwili uzyskania mistrzostwa - jak zauważył Carl Gustaw Jung - „Nie można się obronić przed odrobiną podziwu dla siebie, że się coś lepiej zrozumiało od innych, inni zaś odczuwają potrzebę, by znaleźć gdzieś "namacalnego« bohatera lub górującego nad nimi mędrca, wodza i ojca, niewątpliwy autorytet" (Jung 1981, s. 96-97). Jung zwraca uwagę na naturalny dla tej sytuacji podziw wobec siebie, reprezentowanej przez siebie wiedzy i kompetencji, jednakże ów podziw wyraźnie studzi, postulując o jego niewielkie rozmiary. Potrzeba istnienia mędrca, autorytetu, mistrza wydaje się stała, choć z pewnością podlega ona procesom ewolucji, a w dobie niewątpliwego kryzysu autorytetów jest tym wyraźniej oczekiwana.

Chronicznie potrzeba nam takich mistrzów, do jakich zaliczyć można profesora literatury Tadeusza Makowieckiego, o którym jego uczeń Czesław Zgorzelski pisał tak:

Wyrażała się w tym bodaj cała jego natura, otwarta ufnie wobec innych ludzi; a także prawdziwie humanistyczna potrzeba przyjaźni, wspólnego, kameralnego przeżywania świata i własnej egzystencji wraz z podobnie reagującą, czujną refleksyjnie i emocjonalnie wrażliwością innego, zaprzyjaźnionego z nim człowieka (Zgorzelski 1983, s. 109).

Aby uniknąć tendencyjności i jednostronnego ujmowania tematu, trzeba uczciwie przyznać, że takich Mistrzów w nauce nie brakuje. Ich postawa dalece wykracza poza transmisję wiedzy, wstępując w obszar tego, co Johann Fichte (2012) określa mianem uniwersyteckiego kształtowania wrażliwości, traktując tę kompetencję jako równie ważną co sam proces zdobywania wiedzy, nie wyłączając z potrzeby jej kształtowania także akademików.

Aleksander Nawarecki w interesującej pracy, która ukazała się pod znamiennym tytułem $Z$ tęsknoty za mistrzem, uznaje, że obcowanie z nim przynosić może przyjemności trojakiego rodzaju - zawodowe, estetyczne oraz etyczne (Nawarecki 2007, s. 116-117). W obrębie kompetencji zawodowych to, co powinno cechować mistrza, to przede wszystkim profesjonalizm i skuteczność, $w$ obszarze estetycznym chodzi o sposób rozwiązywania problemów. Nie mniej ważna, jeśli nie najważniejsza, wydaje się właściwość trzecia - etyczna, która powinna się przejawiać w społecznej przydatności, a także w oznakach dobra, które mistrz czyni dla swojego otoczenia. Naukowcy winni mieć na uwadze to, iż szacunek buduje się nie tylko poprzez reprezentowaną przez siebie wiedzę czy autorytet, ale także (a może właściwie przede wszystkim) poprzez to, o czym pisze Richard Sennett, czyli akty troski wobec innych 
(por. Sennett 2012, s. 70-71). Wystarczy wspomnieć nasze własne doświadczenia z Mistrzami. Niejednokrotnie, $\mathrm{z}$ biegiem lat, zaciera się to, o czym nam mówili, ale doskonale pamiętamy, jakimi byli ludźmi.

Tymi, którzy poza samymi mistrzami konstruują aureolę ich wielkości, są uczniowie, młodzi adepci nauki. Portret ucznia interesująco odmalowuje Andrzej Waligóra, który pisze:

Jest on kimś, kto nie tylko w pełni akceptuje osobę nauczyciela, ale też odczuwa dla niego podziw, szczególny rodzaj oddania i lojalności. Z dumą, niekiedy podszytą zacietrzewieniem, głosi jego wielkość i nieprzeciętne talenty. Wreszcie opromienia też ucznia - z racji bezpośredniego kontaktu, współuczestnictwa i rozwijania idei swego nauczyciela - cząstka chwały mistrza spłynie na niego, zwłaszcza gdy ten już odejdzie. Wychowanek zyskuje wówczas zaszczytnie klasyfikujący przydomek, który także może niekiedy (choć nie musi) rzucać cień wielkiego poprzednika na jego osobiste zasługi - uczeń Husserla, uczeń Tischnera, uczeń Błońskiego (Waligóra 2011, s. 10).

Nietrudno takiej - bądź co bądź - łechcącej ego sytuacji ulec. A przecież uprawianie nauki (w modelu idealnym) nakłada na akademików uznanie własnej omylności w procesie dochodzenia do prawdy (Woleński 1991, s. 78). Inaczej rzecz ujmując, trzeba wskazać, iż uczonych powinna charakteryzować intelektualna pokora wobec przedmiotu poznania (Stróżewski 1991, s. 70-71). Niezwykle trafnie proces ten ujmuje Bogdan de Barbaro:

pyszałkowatość, czyli poczucie, że się wie, zanim się jeszcze czegoś dowiedziało naprawdę, jest zgubna. I sprawia, że człowiek staje w miejscu. Pokora zwykle pomaga ruszyć dalej (...). Jest większa szansa, że coś się urodzi z pokornego „nie wiem” niż z „wiem na pewno, jak jest”. W dodatku „nie wiem” rodzi zaciekawienie, otwiera (Jucewicz 2019, s. 160).

Akademicy zwykle zajmują się daną problematyką wiele lat, co sprzyjać może pojawieniu się naukowej pychy, poczucia omnipotencji czy własnej nieomylności.

Dlatego właśnie Sokratejskie „Wiem, że nic nie wiem” powinno wyznaczać fundamentalne wartości w nauce, dookreślane przez jej wektor podstawowy, czyli wagę tak zwanej uczonej niewiedzy, którą moglibyśmy inaczej nazywać pokorą. Inaczej rzecz ujmując, możemy za Karlem Jaspersem (2000, s. 8-9) powiedzieć, iż poszukiwanie prawdy zawsze powinno się łączyć z dostrzeżeniem własnej niewiedzy i wyzwoleniem się od wiedzy iluzorycznej. Celnie proces ten opisał Tadeusz Sławek: „Jednostka jest wolna ku sobie i dla siebie (mam swoje plany, projekty, ambicje mówi sobie), ale musi być także wolna od siebie, a z pewnością od nadmiaru siebie (nie mogę uczynić wszystkiego, co mi się zamarzy - kontynuuję swój wewnętrzny dialog - bowiem jako indywiduum mogę się spełniać jedynie w sferze, w której moje życie styka się z życiem innych, a tę sferę niszczy wszelki nadmiar tego, co 
wyłącznie jednostkowe). W autonomii biegnę ku sobie, ale $\mathrm{i}$ - w głębokim sensie tego określenia - od siebie (wybujałego, nadmiernego) uciekam" (Sławek 2011, s. 21-22). Wydaje się, że ta ucieczka od wybujałego siebie, od nadmiaru siebie jest szczególnie trudna i niewygodna dla wielu uczonych, którzy zinternalizowali jungowską figurę górującego nad innymi mędrca i ojca.

Ogromną wartość ma tutaj reprezentowanie postawy nastawionej na „nie wiem”, która pozwala doświadczyć tego, co typowe dla „dziecięcego zachwytu”, zadziwienia właściwego dla wczesnych etapów rozwojowych. Owych zadziwień na późniejszych etapach życia chronicznie nam brakuje, gdyż zostają wyparte przez wszechobecne postawy pewności. John Keats interesująco stan ten określa mianem „zdolności negatywnej" oznaczającej akceptowanie niepewności, wątpliwości, rozterek, bez konieczności natychmiastowego poszukiwania przyczyn i udzielania bezdyskusyjnych odpowiedzi.

Polska noblistka Wisława Szymborska w odczycie noblowskim doceniła wagę i znaczenie frazy „nie wiem”, którą tak skrzętnie z naszej codzienności eliminujemy. Warto przywołać jej słowa, gdyż niosą w sobie potężną dawkę tego, przed czym niejednokrotnie się wzbraniamy, tak, jakby przyznanie się do niewiedzy stanowiło jedną z największych zbrodni tego świata:

Dlatego tak wysoko sobie cenię dwa małe słowa: „nie wiem”. Małe, ale mocno uskrzydlone. Rozszerzające nam życie na obszary, które mieszczą się w nas samych i obszary, w których zawieszona jest nasza nikła Ziemia. Gdyby Izaak Newton nie powiedział sobie „nie wiem”, jabłka w ogródku mogłyby spadać na jego oczach jak grad, a on w najlepszym razie schylałby się po nie i zjadał z apetytem. Gdyby moja rodaczka Maria Skłodowska-Curie nie powiedziała sobie „nie wiem”, zostałaby pewnie nauczycielką chemii na pensji dla panienek z dobrych domów, i na tej - skądinąd zacnej - pracy upłynęłoby jej życie. Ale powtarzała sobie „nie wiem" i te właśnie słowa przywiodły ją, i to dwukrotnie, do Sztokholmu, gdzie ludzi o duchu niespokojnym i wiecznie poszukującym nagradza się Nagrodą Nobla (Szymborska 1996).

Nieustanne stawianie sobie pytań, poddawanie na nowo refleksji, negowanie tego, co już się wie, sprzyja postawom twórczym, doskonaleniu własnego warsztatu i poszerzaniu wiedzy, nawet tej, którą można uznać za wiedzę pewną. Owo „nie wiem" otwiera nas na drugiego, ale także pozwala własne myśli i przekonania podać w wątpliwość, z pasją i ciekawością właściwą dziecku, które nieustannie pyta, by wiedzieć.

Przywoływany już de Barbaro słusznie zauważa, iż „nie wiem” nie oznacza rezygnacji czy poddania się, jest to raczej umiejętność „lekceważenia własnych myśli”, a "nie wiem” „wyciąga rękę, pyta i słucha”, dzięki czemu łatwiej się zrozumieć (Jucewicz 2019). Wydaje się, że bez owego „nie wiem” proces intersubiektywnego komunikowania w ogóle nie jest możliwy. Gdy bowiem jesteśmy przekonani, że to my wiemy lepiej, że to my znamy prawdę, niemożliwe jest porozumienie. Stąd tak 
ważne jest owo lekceważenie własnych myśli, by nie dać się im zwieść, by nie pozwolić im narzucać własnej prawdy o drugim, bez wniknięcia w jego prawdę. Nabycie umiejętności lekceważenia własnych myśli pozwala otworzyć się na innego, odrzucić rolę wszechwiedzącego narratora, który zwykle mówi „jak jest naprawdę”. Bez „nie wiem" nie ma zaciekawienia drugim człowiekiem, autentycznego zainteresowania Innym i jego problemami.

\section{Edukacja do niewiedzy}

W polskiej edukacji, i to na wszystkich jej szczeblach, brakuje tego, co można by określić mianem edukowania do niewiedzy, docenienia istotności wątpliwości i rozterek jako kluczowych elementów procesu poznawczego, a także ważnych składowych procesu kształtowania osobowości. Istotne wydaje się tutaj przekonywanie uczniów, studentów, ale i samych siebie, iż mamy pełne prawo przyznania się do nieznajomości jakiegoś tematu, niezrozumienia, a wypowiedzenie tego nie jest dyshonorem. Wręcz przeciwnie - może wskazywać na wysoki stopień samoświadomości i autorefleksji, ale nie oznacza gloryfikowania ignorancji.

Akademicy, a w ślad za nimi studenci i uczniowie zakładają, że przyznanie się do niewiedzy stanowi coś, przed czym należy się bronić, czego za wszelką cenę należy unikać. Trzeba zawsze wiedzieć, niezależnie od tego, czy tej wiedzy jesteśmy pewni. Możemy tym samym postawić hipotezę, iż równie ważne jak przekazywanie różnorodnych teorii czy koncepcji, które stanowią istotę procesu dydaktycznego, jest uczenie tego, jak radzić sobie z trudnościami życiowymi, akceptować własną niedoskonałość, braki i egzystencjalne pęknięcia. Konstruowanie figury nauczyciela perfekcjonisty, który zawsze zna odpowiedź na każde pytanie, nigdy nie popełnia pomyłek, zawsze jest nieomylny, jest konstruktem fałszywym, pokazującym tylko jeden, wyidealizowany i nieautentyczny wymiar człowieka. Poza tym owo przyznanie się do niewiedzy strzeże nas przed wszechwiedzącą pychą, która stanowi naczelną kategorię naszych rozważań.

Zasadne dla prowadzonych przez nas rozważań wydaje się zdefiniowanie kluczowego pojęcia - pychy naukowej. Samą pychę możemy zdefiniować jako „pozbawione podstaw urojone wywyższanie siebie ponad miarę” (Gadacz 2018, s. 259). Wielu filozofów deliberowało o pysze - Heraklit uznawał, że „wielkie mniemanie o sobie jest przeszkodą postępu” (Maksym Wyznawca 1980, s. 179), Seneka uważał pychę za „fałszywy pozór wielkości” (Seneka 1961, s. 392), a Spinoza pisał, iż „pycha jest wtedy, gdy ktoś przypisuje sobie jakąś doskonałość, której w nim nie ma” (Spinoza 1969, s. 276). Istotę pychy trafnie oddał w Sprawach ludzkich Jan Szczepański:

Pycha jest zwykłym przejawem pewności siebie, jest wytworem urojeń o własnej doskonałości i wyższości, jest zachowaniem odpowiadającym tym urojeniom i złudzeniom co do własnych 
możliwości. Pycha może wynikać z przynależności do klasy społecznej, do kategorii zawodowej, do kliki, czy elity, może wynikać z osiągnięć nadmiernie ocenianych. Mądrość jest zawsze skromna. Pycha mobilizuje przeciwko tobie wszystkich, z wyjątkiem mądrych, którzy przejrzeli twoją pychę i lekceważą twoje zadęcia, za którymi niczego nie ma prócz powietrza (Szczepański 1980, s. 213).

\section{Pycha naukowa}

Zwykle usprawiedliwienia degrengolady i upadku obyczajów dopatrujemy się w czynnikach zewnętrznych wobec Akademii. Jak odważnie zauważa jednak Jan Kieniewicz: „To my członkowie Akademii, ciało uczone i uczące stwarzamy najwięcej zagrożeń dla autonomii” (2007, s. 2) (zawłaszczanie uniwersytetu, eliminacja swobód), zagrażamy jej „my sami gdy, porzucamy cnoty i wartości. Wrogami autonomii stajemy się pozwalając sobie na odstępstwa od zasad, godząc się na uzurpację, a na koniec - budując wizję zagrożenia zewnętrznego jako usprawiedliwiającą sytuację" (Kieniewicz 2007, s. 2).

Andrzej Bukowski uznaje, że pycha naukowa „wyraża aprioryczne poczucie wyższości własnej prawdy lub systemu prawd w stosunku do odmiennych (konkurencyjnych) prawd, stanowisk, czy sądów" (Bukowski 1994, s. 59). Podobnego zdania jest cytowany już de Barbaro, który uznaje, iż brak pokory przejawia się w skrajnych i uproszczonych poglądach, ale także nieposzanowaniu stanowisk odmiennych. Tak również postrzegał pychę Józef Tischner, dla którego była ona zarzewiem zła, otwarciem się na iluzję co do własnej wartości, przy jednoczesnym poniżeniu innych (Tischner 1990, s. 208).

Jeśli przyjrzymy się wykładowi, który można odczytywać jako modelowy przykład transmisyjnego pasa wiedzy, nietrudno zrozumieć, dlaczego właśnie ta sytuacja może rodzić pychę (por. Szpunar 2017a). Ciekawie na ten temat pisze Piotr Orlik: „Wykładowca upajać się może władzą, jaką roztacza nad słuchaczami za pomocą słów, a słuchacze z kolei mogą być oczarowani, zniewoleni przez słowa wykładwcy: zniewoleni w milczeniu; lub też mogą tylko udawać, że słuchają i w ten sposób zawłaszczyć sobie mówienie wykładowcy" (Orlik 2000, s. 70). W takiej sytuacji nietrudno o to, co określa się mianem narcyzmu sytuacyjnego (Halpern 2007). Inaczej rzecz ujmując, możemy powiedzieć, iż mistrz buduje swój autorytet, uwodząc publiczność. Jak pisze Tomasz Leszniewski: „Potrzebuje on podziwu publiczności opartego na zazdrości ucznia, aby być jak mistrz, wyrażającego zarazem chęć bycia kimś innym niż jest" (Leszniewski 2019, s. 25). Uczniowie są dla mistrza niezbędni, gdyż podtrzymują jego pozycję, zakładając, że nigdy nie będą mistrzem, a próby porównywania się z nim od samego początku skazane są na fiasko, co Barney G. Glaser (1964) określa jako „porównywalną porażkę”. 
Teatralizującą, ale także w pewnym sensie sakralizującą funkcję akademickiego wykładu, szczególnie sprzyjającą postawom pełnym pychy i przekonania o własnej omnipotencji, znakomicie oddają Pierre Bourdieu i Jean-Claude Passeron:

Wzniesiony i zamknięty w przestrzeni, która go uświęca, mówca - oddzielony od audytorium o tyle, o ile pozwala tłok audytorium, kilkoma opustoszałymi rzędami, które materialnie zaznaczają dystans, jaki profan trwożliwie zachowuje wobec mana słowa i które nigdy nie są zajęte, a jeśli już zajęte, to jedynie przez gorliwców w najlepszym stylu, pobożnych ministrantów mentorskiej mowy - profesor odległy i nieprzystępny, otoczony przez niepewne i lękliwe „mówi się”, jest skazany na teatralny monolog i na wirtuozowski pokaz przez przymus pozycji bardziej bezwzględny niż najsurowsze przepisy. Katedra wyłudza - niezależnie od woli osoby na nią wstępującej - intonację, dykcję, wymowę i przebieg wypowiedzi (Bourdieu, Passeron 2011, s. 196).

Akademicki występ przywodzi na myśl kościelną homilię, w której słuchacze zmuszeni są do bezwarunkowej akceptacji prawd płynących $\mathrm{z}$ ambony. I właśnie wtedy, gdyż uczony uznaje, iż posiadł prawdę i ma na nią monopol, to jest to przejaw pychy. Francuscy uczeni zwracają uwagę, iż „pozory erudycji zwalniają od oryginalności badań, a pozór twórczej improwizacji może zwolnić i od klarowności, i od erudycji” (Bourdieu, Passeron 2011, s. 220).

Prowadzi to do sytuacji, w której język przestaje „stanowić narzędzie komunikowania, a służy jedynie jako narzędzie zaklęć, którego funkcją naczelną jest poświadczać i narzucać autorytet pedagogiczny" (Bourdieu, Passeron 2011, s. 198), w konsekwencji ,wielkie słowa mentorskiego wywodu są jeno hasłami lub sakramentalnymi zwrotami rytualnego bełkotu" (Bourdieu, Passeron 2011, s. 205). Dlatego też bywa tak, że znakomici uczeni nie radzą sobie z akademicką sceną, pozostają świetnymi uczonymi w piśmie, ale niekoniecznie znakomitymi oratorami, potrafiącymi przekonać do siebie niejednokrotnie znudzonych słuchaczy. Wartość tego, co się mówi, ma znaczenie wtórne wobec tego, jak się mówi. Ważne, by przekonać słuchaczy, że się wie, że jest się ekspertem w temacie.

Ów naukowy samozachwyt i pełne pychy samozadowolenie próbuje studzić Krzysztof Wielecki, który zauważa:

Potrzebny jest mocny głos niezgody na naukę zbyt łatwą, nadmiernie narcystyczną. Niezbędne jest stałe przypominanie, jak niepewna jest wiedza, którą z takim przekonaniem niekiedy gromadzimy, jak wiele w niej z umownej konwencji i jak dyskretnie poukrywane są w niej ciągotki do panowania, monopolu intelektualnego. Potrzebny jest taki trudny uczeń w klasie, który zawsze rozumie coś innego niż reszta, z czymś się nie zgadza, w coś wątpi. Niezbędną ingrediencją nauki jest bunt, ironiczny uśmiech, nadpobudliwość i nadwrażliwość (Wielecki 2003, s. 245). 
Pytanie, czy rzeczywiście jesteśmy zainteresowani przełamywaniem monopolu intelektualnego, monokultur akademickich i hegemonicznego panowania nad słabszymi, czy też raczej zadowala nas możliwość dominacji i sprawowania kontroli? Wydaje się, że w uniwersyteckiej grze przede wszystkim chodzi o utrzymanie status $q u o$, utrzymanie praktyk feudalnych, tak mocno zakorzenionych w uniwersyteckiej strukturze.

Owe pozoranctwo, ale także fikcjonalność naukowych rytuałów trafnie odsłaniają wzmiankowani już Bourdieu i Passeron:

Dwa razy w tygodniu, na godzinę, profesor musiał się pojawić przed audytorium ukształtowanym przypadkowo, częstokroć złożonym na kolejnych wykładach z osób zupełnie różnych. Musiał mówić, nie troszcząc się o szczególnie potrzeby uczniów, nie dowiadując się, co wiedzą, a czego nie wiedzą (...). Ominąć trzeba było długie dedukcje naukowe wymagające śledzenia całej serii rozumowań. Otwarte dla wszystkich, stające się teatrem dla pewnego typu konkurencji, której celem jest przyciągnięcie i zatrzymanie publiczności, czym są tak oczekiwane wykłady na wyższych studiach? Błyskotliwymi przedstawieniami, „recytacjami” na wzór deklamatorów rzymskiej dekadencji (...) ton profesora niemal nigdy nie dydaktyczny, nieraz deklamatorski, owa zręczność w znajdywaniu oklepanych frazesów, które nie uczą niczego nowego, ale które niezawodnie wywołują znaki aprobaty (Bourdieu, Passeron 2011, s. 218).

Trudno zresztą o znaki dezaprobaty, kiedy struktura wykładu ma charakter iście monologowy, a ewentualne pytania o uwagi, komentarze padają na minutę przed końcem wykładu, tak by skutecznie zniechęcić studentów do ich zadawania. Zresztą, jak piszą francuscy uczeni:

Profesor może nawoływać studentów do udziału bądź wyrażania zastrzeżeń, mając pewność, że nigdy nie będą one miały miejsca. Pytania skierowane do audytorium najczęściej mają charakter retoryczny, a odpowiedzi, przeznaczone głównie do wyrażenia udziału wiernych w nabożeństwie (Bourdieu, Passeron 2011, s. 197).

Pełna pychy „nieomylność mistrza” przejawia się w „profesorskiej ideologii "marności« studentów, będącej mieszaniną najwyższych wymagań oraz pełnej rozczarowań pobłażliwości” (Bourdieu, Passeron 2011, s. 200).

\section{Rodzaje pychy naukowej}

Zajmujący się problematyką pychy naukowej Bukowski (1994, s. 59-62) uznaje, iż możemy mówić o czterech podstawowych jej rodzajach - technokratycznej, scholarskiej, nowatorskiej i scjentystycznej. Pycha technokratyczna przejawia się w przekonaniu o wyższości własnej wiedzy, wynikającej z praktycznych umiejętności nad 
wiedzą teoretyczną, niemającą częstokroć związku z praxis. Umiejętności techniczne, wyrażające się w praxis, pozwalają stwierdzić, że skoro potrafię, to także na pewno wiem. Inaczej rzecz ujmując, kryterium prawdziwości zasadza się na możliwości wykonania czy skonstruowania. Takie rozumowanie sprowadza naukę do reprezentowania interesów technicznych (Habermas 1983, s. 370-401), a to, czego nie da się zweryfikować empirycznie, traktuje się jako mało znaczące, niepotrzebne i nieważne. Ów dylemat trafnie dekonspiruje Florian Znaniecki w znakomitej pracy Społeczne role uczonych, zauważając:

Jak to możliwe, że uczeni - ludzie, którzy pozwalają sobie na uprawianie wiedzy, zamiast jak wszyscy zajmować się działalnością przynoszącą bezpośrednie skutki praktyczne - są nie tylko tolerowani przez ludzi czynu, ale i obdarzani społecznym statusem przez zbiorowość, uznającą, że wypełniają oni pożądaną funkcję społeczną? (Znaniecki 1984, s. 303)

\section{Pycha scholarska}

Wydaje się jednak, iż znacznie częściej spotkać się można w nauce z przejawami pychy scholarskiej. Oznacza ona przekonanie o wyższości własnej szkoły czy reprezentowanego paradygmatu nad innymi. Jak trafnie zauważa Bukowski, reprezentanci danego nurtu dekretują wypowiedziane przez mistrzów (założycieli szkoły) poglądy jako jedynie prawdziwe i słuszne. (...) Udział w „prawdzie szkoły” zobowiązuje jej strażników do pilnowania ortodoksji i piętnowania odchyleń, daje jednak poczucie pewności i przewagi nad pozostałymi (konkurencyjnymi) szkołami lub kierunkami (...), fakty nie potwierdzające tez własnej szkoły uznane zostają za fałszywe, podobnie jak fakty potwierdzające prawdziwość systemów konkurencyjnych (Bukowski 1994, s. 60).

Niejednokrotnie zwolennicy danego nurtu czy danej szkoły są tak dalece zafiksowani na podtrzymywaniu nadrzędności własnego paradygmatu nad innymi, że niemożliwe jest podjęcie jakiejkolwiek dyskusji z jej reprezentantami, którzy negują wszystko, co wykracza poza ich perspektywę. Józef Kozielecki pisze wprost o ostrych i emocjonalnych konfliktach w nauce:

Mniej dojrzali dyskutanci tracą czasem kontrolę nad swoimi emocjami i zamiast przytaczania rzeczowych argumentów popisują się agresją lub złośliwym dowcipem. Jeden z profesorów medycyny, który pracował w Niemczech na początku dwudziestego wieku, z pogardą odnosił się do psychoanalizy. Gdy proponowano mu przedyskutowanie teorii Freuda, krzyczał: „To nie jest temat do dyskusji na posiedzeniu naukowym, to jest sprawa dla policji” (Kozielecki 1979, s. 157). 
Ten cytat doskonale odzwierciedla temperaturę wielu akademickich sporów, które dalekie są od wyważonego, opartego na argumentach dyskursu, z którym zwykle kojarzymy Akademię.

W tym kontekście niezwykle aktualna staje się rozprawa Immanuela Kanta Spór fakultetów; przywołajmy jej fragment:

Wyższe fakultety powinny ponad wszystko zatroszczyć się o to, ażeby nie popełnić mezaliansu z niższym fakultetem, lecz by zachować w stosunku do niego pełen szacunku dystans, ażeby autorytet ich statusu nie został zachwiany pod wpływem wolnej gry rozumowej fakultetu niższego (Kant 2011, s. 206).

Nowoczesny uniwersytet mocno strzeże granic, wyznacza linie demarkacyjne, obszary, za które wchodzić nie wolno, a przynajmniej nie powinno. Zagorzali zwolennicy „wyższych fakultetów”, negując wartość tych niższych, zdają się zapominać, że to, co najciekawsze w nauce, dzieje się na styku, na rubieżach, przez wielu świadomie pomijanych.

Sztuczne tworzenie ram i granic w uniwersytecie, który powinna cechować przede wszystkim wolność i niezależność badawcza, nie powinno mieć miejsca, gdyż staje się dla nauki dysfunkcjonalne. Już w 1852 roku John Henry Newman (1990) wyrażał niepokój o „wąskie” uprawianie nauki i specjalizowanie się jedynie $\mathrm{w}$ wybranej gałęzi wiedzy, z pominięciem, a nawet świadomym ignorowaniem innych dyscyplin. Wartość w tym znaczeniu nabiera to, co Lindsay Waters (2009) określa mianem „szerokiego czytania” przekraczającego granice danej dyscypliny. Paul Feyerabend (1996), autor inspirującej monografii Przeciw metodzie, postulował wręcz o anarchizm epistemologiczny, zwracając uwagę na opresyjny charakter nauki, która tłamsi indywidualizm i wąsko wtłacza w określoną dyscyplinę, dookreślając, co dozwolone, a co obce, a w związku z tym nieakceptowalne.

Takie kurczowe trzymanie się obranej teorii bywa tym, co ogranicza, uwstecznia, ale przede wszystkim uniemożliwia dostrzeżenie niedociągnięć, braków i przekłamań własnej szkoły, co jest szczególnie widoczne w jakże mozaikowej humanistyce. Trzeba przy tym pamiętać, iż nierzadko prowadzone przez akademików spory mają charakter jałowy, gdyż de facto „nie ma możliwości dotarcia do jakiejkolwiek »definitywnej«czy "prawdziwej« rzeczywistości, bowiem taka nie istnieje" (Melosik 2001, s. 147). Pomimo to codziennością uniwersytetu są widoczne antagonizmy sympatyków danych szkół i teorii, których zwolennicy próbują przejąć palmę pierwszeństwa w interpretowaniu i wyjaśnianiu rzeczywistości społecznej. W takim, niemal fanatycznym, zaangażowaniu przestaje chodzić o prawdę, chodzi raczej o wyższość własnych racji i ich niepodważalność, co z uprawianiem nauki ma niewiele wspólnego. Obrona racji własnego paradygmatu czy mistrza jest czasem tak intensywna, że antagonizuje całe instytuty, które pękają w pół, dzieląc się na zwolenników i przeciwników danego nurtu. Implikuje to dogmatyzm i nietolerancję, 
a w konsekwencji regres nauki. Zamiast twórczej dyskusji i fermentu mamy do czynienia z zamknięciem się na inną prawdę. Napiętą sytuację na wielu uczelniach dostrzegają młodzi uczeni, którzy dopiero wkraczają do tego środowiska: „jest ten problem gdzie takich napięć personalnych pomiędzy profesorami u nas i to w pewien sposób rzutuje na relacje między doktorantami, tak, to znaczy, mimo że to zabrzmi trochę kuriozalnie, to doktoranci, $\mathrm{z}$ tych różnych zakładów... no z pewną, z dużą dozą nieufności do siebie podchodzą" (Zawadzki 2017, s. 146).

Anthony Storr w monografii poświęconej autorytetom, osobom uznawanym przez otoczenie za guru zwraca uwagę, że naznaczenie kogoś przez otoczenie takim statusem wykrzywia i patologizuje owe osobowości nader często (Storr 2009, s. 204). Autorytet możne na nas oddziaływać już poprzez sam tytuł, który posiada, reprezentowaną przez niego funkcję czy władzę, o czym wnikliwie pisał Stanley Milgram (2008). Nietrudno w takiej sytuacji o nadużycia, włącznie z bezrefleksyjnym poddaniem się tym, którzy wykorzystują relacje nadrzędności do swoich partykularnych celów. Układ relacji o charakterze asymetrycznym skazuje jednostki podrzędne względem mistrza na uległość i podporządkowanie (Kempny, Szmatka 1992).

Trzeba wspomnieć, iż wielu pracowników nauki jest socjalizowanych do milczenia i bezwzględnego posłuszeństwa wobec profesora, szefa instytutu czy katedry, co zwykle łączy się z wysokimi kosztami psychicznymi. Jak pokazują badania, bycie ocenianym przez innych ludzi należy do najbardziej stresujących doświadczeń ludzkich (Wilkinson, Pickett, 2019). Częsta i bezpardonowa krytyka deformuje powinności uczonego, wywołując u młodych adeptów nauki zaniżone poczucie wartości, niewiarę we własne kompetencje, a w konsekwencji bierne poddanie się autorytetowi.

Badania prowadzone przez Nyssę J. Silbiger i Amber D. Stubler (2019) pokazały, że ostra krytyka, która pojawia się w recenzjach naukowych, wywołuje u uczonych poważny dyskomfort psychiczny, podkopuje wiarę w siebie i spowalnia rozwój kariery zawodowej. Rafał Adamczewski ujmuje to tak:

Pisząc o destrukcji, mam na myśli sytuację, w której strona krytykowana postrzega krytykę jako bezpardonowy atak na jej podmiotowość, kompetencje, kwalifikacje, wiedzę, umiejętności itp., co skłania ją do odparcia ataku. Pojawia się wówczas „ostra” wymiana zdań, która nie tylko uniemożliwia rozwój wspólnoty, ale również może stać się przyczyną jej rozpadu (Adamczewski 2010, s. 41).

Adamczewski opisuje jednak sytuację, w której status rozmówców jest taki sam albo przynajmniej porównywalny; w przypadku pracowników o nierównym statusie trudno mówić o jakiejkolwiek wymianie zdań. Zwykle mamy raczej do czynienia $\mathrm{z}$ milczącą aprobatą, pomimo wewnętrznego sprzeciwu.

Warto również zauważyć, że dążący do podporządkowania sobie podwładnych często wytwarzają iluzję zamkniętego świata, wszechmocy zwierzchnika, od którego zależeć ma wszystko - przyszła kariera (bądź jej brak), zdobywanie kolejnych stopni, 
a nawet prywatne życie, w które ingerują. Młodzi ludzie ulegają złudnemu wrażeniu, że bez wsparcia i pomocy mentora nie są w stanie nic osiągnąć, należy więc dbać o relacje z nim. Ta patologiczna zależność jest kształtowana latami, nierzadko za pomocą zastraszania, blokowania, ale także odmawiania wiedzy i kompetencji.

John Morrissey zwraca uwagę na funkcjonowanie na uczelniach swoistych monokultur (Morrissey 2015), które przejawiają się homogenizacją myślenia i eliminowaniem tego, co wykracza poza uznane. A przecież, jak zauważa Andrew Sayer, autonomia jednostki w miejscu pracy wyraża się poprzez możliwość bycia zauważonym i wysłuchanym, włącznie $\mathrm{z}$ wyrażeniem zdania przeciwnego do „obowiązującego", bez ryzyka bycia upokorzonym, nawet wtedy, gdy nie posiada się pełnych argumentów (Sayer 2007) lub gdy w tej strukturze znajduje się niżej od pozostałych. Michał Zawadzki zwraca uwagę na inny istotny w tym zakresie problem - „naśladownictwa cudzych poglądów, często tylko z powodu posiadanego tytułu czy miejsca w hierarchii organizacyjnej zajmowanego przez ich wyrazicieli” (Zawadzki 2017, s. 144). Bywa tak, że cytuje się kogoś wyłącznie dlatego, że cytować wypada. Zawadzki odsłania ważny problem polskiej nauki, określając praktyki spotykane w akademii jako „kartel intelektualny”, oparty na wzajemnych cytowaniach, ale także fikcyjne współautorstwo, które zwiększa liczbę publikacji.

Warto w kontekście prowadzonych przez nas rozważań przypomnieć jakże ważne słowa Stanisława Ossowskiego:

Najdoskonalszą formą posłuszeństwa (...) ma być takie posłuszeństwo, kiedy człowiek nie tylko wolę swoją oddaje bez reszty swoim zwierzchnikom, ale kiedy potrafi całkowicie podporządkować im swój sąd; kiedy myśli tak, jak myślą jego przełożeni, kiedy potrafi tak nagiąć swój intelekt, aby przez ślepotę swego posłuszeństwa osiągnąć mądrość i doskonałość (Ossowski 1967, s. 177).

Podmiotowość jednostki, uczonego, zostaje zagarnięta, wchłonięta przez akademicką monokulturę, a człowiek przestaje być w jakikolwiek sposób niezależny, myśląc dokładnie tak, jak myślą jego zwierzchnicy. Taki stan oznacza de facto intelektualną śmierć, ale i odarcie jednostki z jej godności i podmiotowości. Zawadzki w tym kontekście pisze o swoistym „kulcie dostojników”, który oznacza „konieczność poddaństwa względem ich woli w celu przeżycia oraz ukazując ich napuszenie, przyjmujące niekiedy groteskowe formy z powodu często miernej jakości ich dorobku naukowego" (Zawadzki 2017, s. 144). A przecież, jak zauważał Stanisław Ossowski:

Pracownik naukowy to taki człowiek, do którego zawodowych obowiązków należy brak posłuszeństwa w myśleniu. Na tym polega jego służba społeczna, aby pełniąc swe zawodowe czynności nie był w myśleniu posłuszny. Pod tym względem nie wolno mu być posłusznym ani synodowi, ani komitetowi, ani ministrowi, ani cesarzowi, ani Panu Bogu. Jeżeli jest posłuszny, 
jeżeli poglądy swoje zmienia na rozkaz, albo jeżeli myśl jego nie jest w zgodzie z jego słowami, sprzeniewierza się swoim obowiązkom" (Ossowski 1989, s. 36).

I tu wkraczamy w jakże ważny obszar, jeśli chodzi o uprawianie nauki, a mianowicie autonomię badawczą. Zapewnia ona (przynajmniej w typie idealnym) wolność w obszarze prowadzenia badań naukowych, brak ingerencji czy narzucania tego, co należy badać i eksplorować (Lynch, Ivancheva 2015), co wpisuje się w prace danego zakładu, a co nie. Pisze o tym trafnie Piotr K. Oleś:

poważniejszy problem dotyczy sytuacji, gdy zdolny asystent lub adiunkt okazuje się chodzić własnymi ścieżkami, oddalając się od głównego nurtu zainteresowań zespołu i (lub) dystansując się wobec dokonań stylu pracy swojego „mistrza”. Czy można po prostu wymówić takiej osobie miejsce w zespole? Życie uczy, że można (Oleś 2007, s. 22).

Dzieje się tak między innymi dlatego, iż polską kulturę akademicką nadal charakteryzuje feudalizm (Kościelniak 2015; Sułkowski 2016). Oleś pisze wręcz o funkcjonowaniu „praktyk dynastycznych”, które blokują współpracę, wytwarzają rywalizację i kształtują dysfunkcjonalne relacje w zespole. Przypomnijmy Kazimierza Ajdukiewicza, który zauważał, iż faworyzowanie jednych ponad drugimi, ale także konieczność stosowania określonej metody czy konkretnej teorii są niczym innym jak łamaniem wolności uczonego (Ajdukiewicz 1983). Wolność naukowa jego zdaniem powinna się przejawiać wolnością słowa, wolnością myśli, wolnością problematyki, wolnością badania i metody. Wydaje się, że wszystkie typy wolności są w sfeudalizowanej akademii mocno ograniczone.

\section{Pycha nowatorska}

Emanacją pychy nowatorskiej jest odrzucanie dorobku i negowanie przeszłych dokonań. Figura uczonego-eksploratora (Znaniecki 1984, s. 443-478) jest ważna i ceniona w nauce, gdyż dzięki niebanalnym problemom, odważnemu stawianiu nietuzinkowych pytań odbywać się może postęp. Nie powinno to jednak następować przy totalnym negowaniu przeszłości i dokonań poprzedników. Wspominany już uniwersytecki feudalizm ma swoje janusowe oblicze w innym wymiarze, eliminuje bowiem nowatorstwo, innowacyjność czy tak pożądaną odwagę badawczą (Kościelniak 2015). Bywa tak, że szczególnie innowacyjne tematy bywają blokowane, a zdolnym utrudnia się rozwój, traktując ich jako zagrożenie dla tych, którzy raczej upajają się osiągniętą pozycją, niż wykazują potrzebę nieustannego rozwoju.

Uniwersytet to ciągłość, nieustanne opieranie się na ramionach gigantów, niespłacalny dług wobec tych, dzięki którym jesteśmy tym, kim jesteśmy, co trafnie ujmuje Tadeusz Sławek: „Można rzec, że jestem wolny wtedy, gdy mam świadomość 
swego długu wobec innych, auto- jest zadłużone u tego, co hetero-, czyli rozpoznawalne jako »inne«, może nawet »przeciwne«. Kultywowanie poczucia tego długu jest podstawowym zadaniem mądrego kształcenia" (Sławek 2011, s. 22). Istnieje niezrozumiała tendencja do pokazywania, iż jest się w czymś pierwszym, oryginalnym, a przecież w humanistyce trudno o rzeczy całkowicie odkrywcze, a jeśli już takie się pojawiają, to właśnie wtedy, gdy jesteśmy głęboko zanurzeni w dokonaniach innych, budując na starym to, co nowe.

Szerokie czytanie, o którym wspomina Waters, sprawia, że dostrzegamy więcej, jesteśmy bardziej twórczy i innowacyjni. Bywa niestety tak, że pewna grupa uczonych wykazuje tendencje do ukrywania cudzych myśli, wskazywania inspiracji, podając je jako własne, autorskie. O ile sytuacje takie są w pewnym stopniu akceptowalne u nie do końca uświadomionych studentów, o tyle u uznanych pracowników nauki w ogóle nie powinny mieć miejsca.

W znakomitej, acz mało znanej szerszej publiczności monografii Zmierzch wiedzy. Przemiany uniwersytetu a rynek publikacji naukowych Lindsay Waters słusznie zauważa: „W świecie akademickim szerzy się jakaś lękliwość. Zdrowy rozsądek podpowiada, aby nie zadawać fundamentalnych pytań, nie interesować się tym, dlaczego jest, jak jest. (...) Bądź pokornie rozumny, pozostań wierny rzeczom małym” (Waters 2009, s. 35). Czasem ów „zdrowy rozsądek” stanowi wypadkową wyraźnych sugestii przełożonych, którzy pewne tematy uważają za niepoważne, mało naukowe czy w ogóle niewarte podjęcia. Młodzi uczeni, choć reprezentują odwagę i śmiałość badawczą, są negowani przez bardziej doświadczonych, którzy sugerują albo kontynuowanie ich własnych tematów, albo też zajmowanie się tym, co bezpieczne, sprawdzone i niekontrowersyjne. Michał Paweł Markowski nazywa ten trend policyjnym akademizmem, w którym dominują „metody ostateczne, uznane za oczywiste, niezmienne i jedyne godne wykładania" (Markowski 2013, s. 62).

Pycha nowatorska może się również przejawiać dążeniem do sławy, która to, poprzez procesy medialnej widoczności ${ }^{2}$, decyduje o wartości danego uczonego. Widzialność i rozpoznawalność pracownika nauki determinuje jego uznanie. Jak zauważał Piotr Sztompka, „sławni gromadzą nieproporcjonalnie wiele nagród w porównaniu $\mathrm{z}$ ich mniej sławnymi, a nieraz równie zdolnymi kolegami, przez co hierarchia w nauce ma tendencję do wypiętrzania się ponad uzasadnioną miarę" (Sztompka 1999, s. 202).

2 Autorem kategorii „medialnej widoczności” jest John Thompson. Choć autor nie tłumaczy jej wprost, proponuję ją rozumieć jako przekonanie, iż trudno współcześnie funkcjonować bez bycia widocznym, rozpoznawalnym i nieustannie obecnym (por. Szpunar 2017b, s. 494-504). 


\section{Pycha scjentystyczna}

Ostatni typ pychy naukowej to pycha scjentystyczna. To właśnie ona uznaje nadrzędność poznania naukowego nad innymi możliwymi typami wiedzy i wnioskowania. Często uczeni zakładają, że poznanie naukowe jest jedyną możliwą drogą poznania, i to ona powinna określać cele życiowe ludzi i ich wartości. Przypomnijmy, że scjentyści uznawali, iż nauka powinna kreować społeczeństwo i kulturę, które to w głównej mierze opierałyby się na jej osiągnięciach (Ossowska, Ossowski 1967, s. 100-101). Nauka w takiej optyce jawi się jako przestrzeń dostępna dla wybranych i wtajemniczonych strażników nauki, tym samym niedostępna dla profanów (Barycz 1977). Trzeba zwrócić uwagę, iż pycha uczonych niejednokrotnie przejawia się w tym, że legitymizują oni jedynie to, co jest mierzalne i weryfikowalne (zob. szerzej Szpunar 2019a).

Jeśli przyjrzymy się chociażby dyskursowi naukowemu zogniskowanemu wokół emocji, możemy zauważyć, iż traktowane są one jako dyspozycje opozycyjne wobec rozumu. W wielu pracach naukowych utrzymują się potoczne dychotomie - rozum/ emocje, umysł/ciało czy kultura/natura. Współcześnie uznaje się, że emocje i rozum raczej uzupełniają się, niż działają wobec siebie antagonistycznie. Badania wyraźnie wskazują (Damasio 1999), iż w sytuacji, gdy płat przedczołowy jest odłączony od podkorowych ośrodków emocji w mózgu, jednostki niemal nie potrafią podjąć jakichkolwiek decyzji, a jeśli je podejmują, są one nielogiczne i niezrozumiałe. Podejmowanie decyzji i ludzka racjonalność są zatem mocno sprzężone z emocjami (zob. szerzej Szpunar 2019b, s. 47-63).

Pisząc o pysze scjentystycznej, warto zaznaczyć również to, co Edmund Husserl nazywa „zbłąkanym racjonalizmem” (Husserl 1987). Przejawia się on w redukowaniu złożonej i wielowymiarowej rzeczywistości społecznej do sfery faktów i tego, co można empirycznie sprawdzić. Ów zbłąkany racjonalizm odrzuca wszystko to, co niepewne, niepełne, niepoddające się weryfikacji. Zawierzenie zbłąkanemu racjonalizmowi sprawia, że zakładamy, iż wykorzystując metody nauk przyrodniczych, które jako jedyne mają nam zapewnić rygory naukowości, możemy poznać wszelkie wymiary rzeczywistości. Jest to myślenie błędne, gdyż nierzadko mierzymy się z problemami trudno, a czasami w ogóle nieprzekładalnymi na język nauki, a na wiele pytań nauka w ogóle nie potrafi odpowiedzieć.

Rolą akademii powinno być zatem nie tylko pielęgnowanie rozumu, ale i wrażliwości. Johann Fichte w swojej pracy Kilka wykładów o powołaniu uczonego (2012) wyraził przekonanie, że kształcenie uniwersyteckie powinno opierać się przede wszystkim nie tylko na przekazie wiedzy, ale i kształceniu pewnej wrażliwości. Fichte odrzucał uniwersytet oparty wyłącznie na zasadach rozumu: „po uzyskaniu odpowiedniej empirycznej wiedzy [u studenta, a także pracownika nauki - dop. M.S.] powinna się rozwinąć zwłaszcza wrażliwość" (Fichte 2012, s. 70). 


\section{Podsumowanie}

Naczelną kategorią rozważań autorki stała się pycha i jej rozliczne odmiany - technokratyczna, nowatorska, scjentystyczna i scholarska. W artykule opisano jungowską sferę Cienia, związaną z działalnością uczonych, którym zwykle przypisujemy najwyższe standardy etyczne. Rozdźwięk pomiędzy ideałami bywa jednak dość wyraźny i rozczarowujący, a przez to dojmujący. Przyjęcie postawy „nie dostrzegam - nie istnieje” stanowi dla wielu $\mathrm{z}$ nas formę radzenia sobie $\mathrm{z}$ trudnymi do przyjęcia prawdami. Moim zamierzeniem było dotarcie i odsłonięcie tego, co wypieramy, czego nie dostrzegamy (lub wolimy nie dostrzegać), co jednak niczym rak trawi zdrową tkankę akademickiego organizmu. Pycha środowiska naukowego stanowi swoistą białą plamę badawczą, dlatego uznałam za wartościowe poznawczo poświęcić jej niniejsze rozważania, uznając (być może naiwnie), iż proces każdej zmiany społecznej rozpoczyna się od zidentyfikowania i nazwania istniejącego problemu. Problemów trawiących Akademię jest znacznie więcej i bywają znacznie poważniejsze niż to, o czym piszę w niniejszym tekście. Wypowiedzenie wszystkich znacznie przekroczyłoby ramy niniejszego artykułu, a ponadto w wielu przypadkach doczekały się one poważnych opracowań. Pesymistycznie możemy konkludować, że i tak niewiele to zmieniło. Być może w wielu wymiarach tak jest. Trzeba jednak nieustannie poddawać własną pracę autorefleksji, odpowiadać sobie uczciwie, ile daję z siebie innym, ile w tym jest autentycznej troski o innego, a ile - posiłkując się słowami Tadeusza Sławka - nadmiernego siebie. Jaspersowskie uprawianie nauki zawsze powinno się łączyć z dostrzeganiem, ale i pokornym akceptowaniem własnej niewiedzy, co niewątpliwie ma charakter wyzwalający. Husserlowski zbłąkany racjonalizm nie powinien nam przysłaniać tego, co obok wiedzy tak ważne w Uniwersytecie i o co tak żarliwie postulował Fichte - kształtowania wrażliwości.

\section{Bibliografia}

Adamczewski R. (2010), Dialog i krytyka jako niezbędne warunki współpracy i rozwoju teorii i praktyki pedagogicznej, „Przegląd Pedagogiczny”, nr 2, s. 34-44.

Ajdukiewicz K. (1983), Co to jest wolność nauki?, „Zagadnienia Naukoznawstwa”, nr 19 (3), s. 257-264.

Barycz H. (1977), Z dziejów polskiej humanistyki w dobie Młodej Polski. Na przełomie dwóch stuleci, Wrocław: Zakład Narodowy im. Ossolińskich.

Bourdieu P., Passeron J.C. (2011), Reprodukcja. Elementy teorii systemu nauczania, tłum. E. Neyman, Warszawa: WN PWN.

Bukowski A. (1994), Pycha naukowa, [w:] J. Goćkowski, P. Kisiel (red.), Patologia i terapia życia naukowego, Kraków: Universitas, s. 57-63.

Damasio A. (1999), Błąd Kartezjusza. Emocje, rozum i ludzki mózg, tłum. M. Karpiński, Poznań: Rebis. 
Feyerabend P.K. (1996), Przeciw metodzie, tłum. S. Wiertlewski, Wrocław: Wydawnictwo Siedmioróg.

Fichte J. (2012), Kilka wykładów o powołaniu uczonego, tłum. T. Kupś, Toruń: UMK.

Gadacz T. (2018), Uniwersalne prawdy i prawa życia dla mądrych ludzi na trudne czasy, Siedliska: Wydawnictwo Nieoczywiste.

Gibiński K. (2001), Przedmowa, [w:] Dobre obyczaje w nauce. Zbiór zasad i wytycznych, Warszawa: PAN, s. 1-4.

Glaser B.G. (1964), Organizational Scientists: Their Professional Careers, Indianapolis-New York-Kansas City: The Bobbs-Merrill Company.

Habermas J. (1983), Teoria i praktyka, tłum. M. Łukasiewicz, Z. Krasnodębski, Warszawa: Państwowy Instytut Wydawniczy.

Halpern J. (2007), Fame Junkies: The Hidden Truths Behind America's Favorite Addiction, Boston-New York: Mifflin Company.

Husserl E. (1987), Kryzys nauk europejskich i filozofia transcendentalna, tłum. S. Walczewska, Kraków: Wydawnictwo Naukowe Papieskiej Akademii Teologicznej.

Jaspers K. (2000), Autorytety. Sokrates, Budda, Konfucjusz, Jezus, tłum. P. Bentkowski, R. Flaszak, Warszawa: Wydawnictwo KR.

Jucewicz A. (2019), Czując. Rozmowy o emocjach, Warszawa: Wydawnictwo Agora.

Jung C.G. (1981), Archetypy i symbole. Pisma wybrane, tłum., wybór i wstęp J. Prokopiuk, Warszawa: Czytelnik.

Kant I. (2011), Dzieła zebrane, t. 5, tłum. A. Bobko, J. Galewicz, M. Żelazny, Toruń: Wydawnictwo Naukowe Uniwersytetu Mikołaja Kopernika.

Kempny M., Szmatka J. (1992), Wspótczesne teorie wymiany społecznej. Zbiór tekstów, Warszawa: Państwowe Wydawnictwo Naukowe.

Kieniewicz J. (2007), Przyjaciele czy wrogowie, [w:] J. Kieniewicz (red.), Autonomia uniwersytetu. Jej przyjaciele i wrogowie, Warszawa: Fundacja „Instytut Artes Liberales”, Pszczelarska Oficyna Wydawnicza Maciej Rysiewicz, s. 1-4.

Kotarbiński T. (1987), Wypowiedź w dyskusji o etyce zawodowej, [w:] P.J. Smoczyński (red.), Pisma etyczne, Wrocław: Zakład Narodowy im. Ossolińskich, s. 467-469.

Kościelniak C. (2015), Uniwersytet, rozwój, kultura, Poznań: Wydawnictwo Naukowe UAM.

Kozielecki J. (1979), Konflikty w nauce, [w:] tegoż, Nauka i osobowość, Warszawa: Wiedza Powszechna, s. 179.

Krimsky S. (2006), Autonomy, Disinterest, and Entrepreneurial Science, „Society”, Vol. 43, Iss. 4, s. 22-29.

Kwiek M. (2015), Uniwersytet $w$ dobie przemian. Instytucje i kadra akademicka $w$ warunkach rosnacej konkurencji, Warszawa: PWN.

Leszniewski T. (2019), O potrzebie mistrza $w$ świecie nauki, czyli refleksja nad zmieniająca się relacją uczeń - mistrz, „Nauki o Wychowaniu. Studia Interdyscyplinarne”, t. 8, nr 1, s. 22-33.

Lynch K., Ivancheva M. (2015), Academic Freedom and the Commercialisation of Universities: A Critical Ethical Analysis, „Ethics in Science and Enviromental Politics”, No. 15, s. 1-15. 
Maksym Wyznawca (1980), Antologia życia wewnętrznego, tłum. A. Warkotsch, Poznań: Pallottinum.

Markowski M.P. (2013), Polityka wrażliwości. Wprowadzenie do humanistyki, Kraków: Universitas. Melosik Z. (2001), Teoria i społeczne konstruowanie rzeczywistości, „Teraźniejszość - Człowiek - Edukacja”, numer specjalny.

Milgram S. (2008), Posłuszeństwo wobec autorytetu, tłum. M. Hołda, Kraków: Wydawnictwo Smak Słowa.

Morrissey J. (2015), Regimes of Performance: Practices of the Normalised Self in the Neoliberal Academia, „British Journal of Sociology of Education”, Vol. 36, No. 4, s. 614-634.

Nawarecki A. (2007), Maestro Opacki (o ekonomii podziwu), [w:] J. Kurek, K. Maliszewski (red.), Z tęsknoty za mistrzem, Chorzów: Miejski Dom Kultury „Batory”, s. 116-117.

Newman J.H. (1990), Idea uniwersytetu, tłum. i wybór J. Fijas, Warszawa: Państwowe Wydawnictwa Naukowe.

Oleś P.K. (2007), O niektórych etycznych i nieetycznych obrzeżach uprawiania nauki, „Nauka”, nr 4. Orlik P. (2000), Rozum a wrażliwość, [w:] P. Orlik (red.), Rozdroża i ścieżki wrażliwości, Poznań: UAM, s. 59-80.

Ossowska M., Ossowski S. (1967), Nauka o nauce, [w:] S. Ossowski , Dzieła, t. 4, Warszawa: Państwowe Wydawnictwa Naukowe, s. 91-102.

Ossowski S. (1967), Koncepcje ładu społecznego i typy przewidywań, [w:] tenże, Dzieła, t. 4, Warszawa: Państwowe Wydawnictwa Naukowe, s. 173-193.

Ossowski S. (1989), Taktyka i kultura, [w:] J. Karpiński, Nie być w myśleniu posłusznym. Ossowscy, socjologia, filozofia, London: Polonia Book Fund Ltd, s. 129-139.

Pieter J. (1967), Ogólna metodologia pracy naukowej, Wrocław: Ossolineum.

Polanyi M. (1962), The Republic of Science: Its Political and Economic Theory, „Minerva”, Vol. 1, No. 1, s. 54-73.

Sayer A. (2007), Dignity at Work: Broadening the Agenda, „Organization”, Vol. 14, No. 4, s. 565-581. Seneka L.A. (1961), Listy moralne do Lucyliusza, tłum. W. Kornatowski, Warszawa: PWN.

Sennett R. (2012), Szacunek w świecie nierówności, tłum. J. Dzierzgowski, Warszawa: Warszawskie Wydawnictwo Literackie Muza.

Silbiger N.J., Stubler A.D. (2019), Unprofessional Peer Reviews Disproportionately Harm Underrepresented Groups in STEM, „PeerJ”.

Sławek T. (2011), Autonomia, kształcenie, dług, [w:] C. Kościelniak, J. Makowski (red.), Wolność Równość Uniwersytet, Warszawa: Instytut Obywatelski, s. 21-32.

Spinoza B. (1969), Pisma wczesne, tłum. L. Kołakowski, Warszawa: PWN.

Stróżewski W. (1991), Kilka uwag o prawdzie, [w:] J. Goćkowski, K. Pigoń (red.), Etyka zawodowa ludzi nauki, Wrocław-Warszawa-Kraków: Zakład Narodowy im. Ossolińskich, s. 65-72.

Storr A. (2009), Kolosy na glinianych nogach. Studium guru, tłum. J. Prokopiuk, P.J. Sieradzan, Warszawa: Wydawnictwo W.A.B.

Sułkowski Ł. (2016), Kultura akademicka. Koniec utopii?, Warszawa: Wydawnictwo Naukowe PWN.

Szczepański J. (1980), Sprawy ludzkie, Warszawa: Czytelnik. 
Szpunar M. (2017a), Postawy narcystyczne wśród pracowników nauki, „Horyzonty Wychowania", nr 39, s. 47-58.

Szpunar M. (2017b), Medialna widoczność jako emanacja hiperobecności, „Zeszyty Prasoznawcze”, nr 3, s. 494-504.

Szpunar M. (2019a), Kwantyfikacja rzeczywistości. O nieznośnym imperatywie policzalności wszystkiego, „Zeszyty Prasoznawcze”, nr 3, s. 95-104.

Szpunar M. (2019b), (Nie)potrzebna wrażliwość, Kraków: IDMiKS UJ.

Sztompka P. (1999), Merton, Robert King, [w:] H. Domański, Z. Bokszański (red.), Encyklopedia socjologii, t. 3, Warszawa: Oficyna Naukowa, s. 199-203.

Szymborska W. (1996), Poeta i świat - odczyt noblowski 1996 rok, https://www.nobelprize.org/ prizes/literature/1996/szymborska/25586-wislawa-szymborska-odczyt-noblowski-1996/ [odczyt: 22.03.2020].

Tischner J. (1990), Filozofia dramatu, Paris: Edition du Dialogue.

Waligóra A. (2011), Mistrz i nauczyciel - zaniedbany archetyp, „Annales Universitatis Paedagogicae Cracoviensis Studia ad Didacticam Litterarum Polonarum et Linguae Polonae Pertinentia III", s. 7-19.

Waters L. (2009), Zmierzch wiedzy. Przemiany uniwersytetu a rynek publikacji naukowych, tłum. T. Bilczewski, Kraków: Wydawnictwo Homini.

Wielecki K. (2003), Podmiotowość w dobie kryzysu. Między indywidualizmem a kolektywizmem, Warszawa: Centrum Europejskie Uniwersytetu Warszawskiego.

Wilkinson R., Pickett K. (2019), The Inner Level: How More Equal Societies Reduce Stress, Restore Sanity and Improve Everyone's Wellbeing, London: Penguin Press.

Woleński J. (1991), Aksjologia i metodologia, [w:] J. Goćkowski, K. Pigoń (red.), Etyka zawodowa ludzi nauki, Wrocław-Warszawa-Kraków: Zakład Narodowy im. Ossolińskich, s. 73-78.

Zawadzki M. (2017), Między neoliberalizmem a feudalizmem. Godność młodych naukowców $w$ kontekście transformacji polskiego uniwersytetu, „Nauka i Szkolnictwo Wyższe”, nr 1, s. $133-154$.

Zgorzelski C. (1983), Mistrzowie i ich dzieła, Kraków: Społeczny Instytut Wydawniczy Znak. Znaniecki F. (1984), Społeczne role uczonych, Warszawa: PWN. 